\title{
Geocaching, a tool to support environmental education!?- An explorative study
}

\author{
Stefani Zecha \\ Catholic University Eichstätt. \\ Germany
}

\begin{abstract}
:
This article focuses on an increasingly popular idea: geocaching in combination with environmental education. The author will look at possible ways in which geocaching can be optimally used within environmental education. In the theoretical part, the author first defines environmental education and then examines the current discussion at the interface of geocaching and environmental education. Out of the theoretical part, the following questions arise: Which specific characteristics of a geocaching route might be useful for environmental education? What are the specific characteristics of a cache which might be suitable for environmental education? To answer these questions, the author used a qualitative interview study. In the findings section, the results of the interviews will be presented. Some of the different opportunities to use geocaching within the realm of environmental education will be discussed. Finally, the author will present some ideas on how investigations in this area might progress in future.
\end{abstract}

Keywords: environmental education, geocaching, pupil, GPS

Corresponding author: Stefani Zecha

E-mail: stefanie.zecha@ku-eichstaett.de

Educational Research eJournal - ISSN 2254-0385

(C) Faculty of Education. University of Alicante- Spain

DOI: $10.5838 /$ erej.2012.12.06 


\section{Introduction: Nature as Adventure}

A growing alienation from nature has been observed among juveniles in recent years (Brämer 2006). Yet, a basic understanding of the connections between environmental, economic, and social factors and their appreciation is a crucial requirement for environmental conservation. To ensure this conservation in the future, children and juveniles must develop skills for approaching and investigating natural and cultural phenomena and the ability to associate various perspectives (or phenomena) with each other (Lude 2005). Teenagers need their own experience of nature, as this is more effective than through knowledge transfer, for example in classroom (Cornell 1991). One of the consequences of experiencing nature first-hand is that teenagers develop a relationship with nature. They profit from this connection and; so does the planet. Interaction with nature can start a process which gives meaning to nature (Schleicher 1997, p.175). Zecha (2010) showed in her study that nature experiences have an explanatory value for environmental consciousness. Nature experiences are also a very important step for attracting pupils to environmental action (Zecha 2010). Parallel to this development, juveniles are very familiar with using modern information media, be it mobile phones or the internet (TULLY 2004, P. 14 et. Seqq.). The logical next step is therefore to utilise this new technology for environmental education purposes. Satellite navigation systems are now being used as a medium to reintroduce teenagers to nature (Hartl 2006, p.70). Special geocaching routes have been created in Germany which use the method of geocaching to make teenagers in particular familiar with environmental themes and give them the opportunity to experience nature first-hand (2.2). Now, the significant question is how geocaching routes can be arranged to best fulfil the criteria laid out by environmental education. A major purpose of the present study was to do research using qualitative interviews with experts in the field to answer this very question.

\section{Theory: Overview of Current Research}

\subsection{Environmental education}

The roots of environmental education can be found in the early 1970s. The foundations for environmental education were published in the Belgrade Charter (UNESCO 1976) and ratified as the Tbilisi Declaration (UNESCO 1978): "Environmental Education (EE) is a process in which individuals gain awareness of their environment and acquire knowledge, skills, values, experiences, and also the determination which will enable them to act individually and collectively - to solve present and future environmental problems." (UNESCO 1978).

The components of environmental education are (Siva Laxmi 2010, p. 10):

1. Knowledge - gaining understanding of the environment and environmental challenges

2. Skills - acquiring the necessary skills to identify environmental problems

3. Participation - providing opportunities to be actively involved at all levels in working towards the resolution of environmental problems

4. Awareness - acquiring a sensitivity towards the total environment and its problems and a sensitivity towards the environment and environmental challenges 
5. Attitudes - acquiring a set of values and emotions of concern for the environment and the motivation for active participation in environmental improvement and protection.

Environmental education enhances critical thinking, problem-solving, and effective decision-making skills, and teaches individuals to weigh up various sides of an environmental issue to make informed and responsible decisions. Environmental education does not advocate a particular viewpoint or course of action (Siva Laxmi 2010, p. 15 ).

According to this definition, environmental education greatly overlaps with education for sustainability, especially within the areas of ecology, society and culture and, to a lower degree, with economics. Meaningful encounters with nature as a 'special event' can get easily confused with education for sustainability. For this reason, the author focused on the term 'environmental education' instead of 'education for sustainability'.

\subsection{Learning with digital media: Geocaching and environmental education}

According to the definition, digital media consist of hardware, such as computers, notebooks or GPS receivers and of software, such as geo-information software and the Internet (Schleicher 2006). The following aspects of environmental education can be supported with the help of digital media: problem-oriented learning, value learning, cooperative learning, action-oriented learning and participation (Riess 2006, p. 70f). Riess (2006) shows in his investigation that knowledge transfer in the field of environmental education with the help of digital media, but without spending time in nature, is not really successful. Geocaching is one method to use digital media outside. "Geocaching is a high-tech treasure hunting game played throughout the world by adventure seekers equipped with GPS devices. The basic idea is to locate hidden containers, called geocaches, outdoors, and then share your experiences online" (Groundspeak 2010). The objective of geocaching is to guide people to extremely attractive places, where they can find a cache using GPS-devices and corresponding coordinates posted online (Gründel 2009, Burt Lo 2010, www.geocaching.com,

www.opencaching.de, www.geocachingevents.de, Telaar 2007). This method has been making its way into education more recently (Koller 2010, Ihamäki 2007, Tyszkowski 2009, Christie 2007, Dobyns 2008) and also into environmental education (Hartl 2006, Patubo 2010, Ecomove 2011 A, Aktion Fischotterschutz 2011). Each geocaching route deals with a special theme within environmental education. Each cache of the route covers one aspect of the topic. There is learning content in the caches, which is connected to a specific place and which you find with the help of coordinates and a GPS receiver. The consequence is that the juveniles learn how to orientate themselves within nature. They obtain interesting information about nature at the same time. People are captivated by this method within the field of environmental education, as bringing juveniles back to nature sets an important challenge. High Tech gadgetry provides a bridge to nature, especially for juveniles, who often show no interest in nature initially and do not often spend time outdoors (Hartl 2006). There is scarce literature on this theme (Schäfer 2010, Patubo 2010, Hartl 2006), however, Hartl (2006) evaluates a geocaching route on environmental themes which involves various tasks. The results are not very profound. With 
respect to environmental education, he came to the conclusion that nature experiences are possible with the help of GPS devices, but in the same way as with normal guided tours. There are no outstanding results in relation to knowledge acquisition or skill improvement. Patubo (2010) focuses in his thesis on the negative consequences of geocaching to nature. In particular, he points out the negative impact of geocaching trails on the vegetation and soil in cache box areas. Schäfer (2010) describes the construction of a GPS route in his bachelor thesis on environmental education around Oldenburg. His work focuses on special computer software known as audio geo-information-systems for tourists, which can be used on small pocket computers. He investigates how functional it is. In this GPS route, various aspects of the landscape are explored for their historical, cultural and technical value, as well as numerous plants and environmental features. Finally, he presents the advantages and disadvantages of this program of geocaching routes in nature. Some of the disadvantages include the finding that plants only appear for a short time and you cannot react spontaneously with events in nature. Some advantages are that you do not need to pay for signs on the route to explain notable aspects of the landscape. Also, people can use the technology independently of a guide
(Schäfer 2010). In their works, Schäfer, Patubo and Hartel do not recognise all aspects of environmental education equally (2.1). In comparison to this study, Hartl (2006) and Patubo (2010) stress the knowledge aspect most of all; other aspects of environmental education, such as the skills to identify problems in nature, or participation, are not treated. This investigation offers a broader and deeper understanding of geocaching and environmental education.

The questions which arise from this are therefore:

-What are the specific characteristics of a route that would be useful for environmental education?

-What are the specific characteristics of a cache that would be suitable for environmental education?

\section{Methods}

\subsection{Empirical Research Design}

The empirical research design is illustrated in the figure below. The decision for a purely qualitative design was made because of the social significance of geocaching routes and because there have only been a few scientific works about the relationship between environmental education and geocaching (Schäfer 2010, Hartl 2006, Patubo 2010). As a data base, interviews and existing geocaching routes within the area of environmental education are used.

Fig 1. Research Design

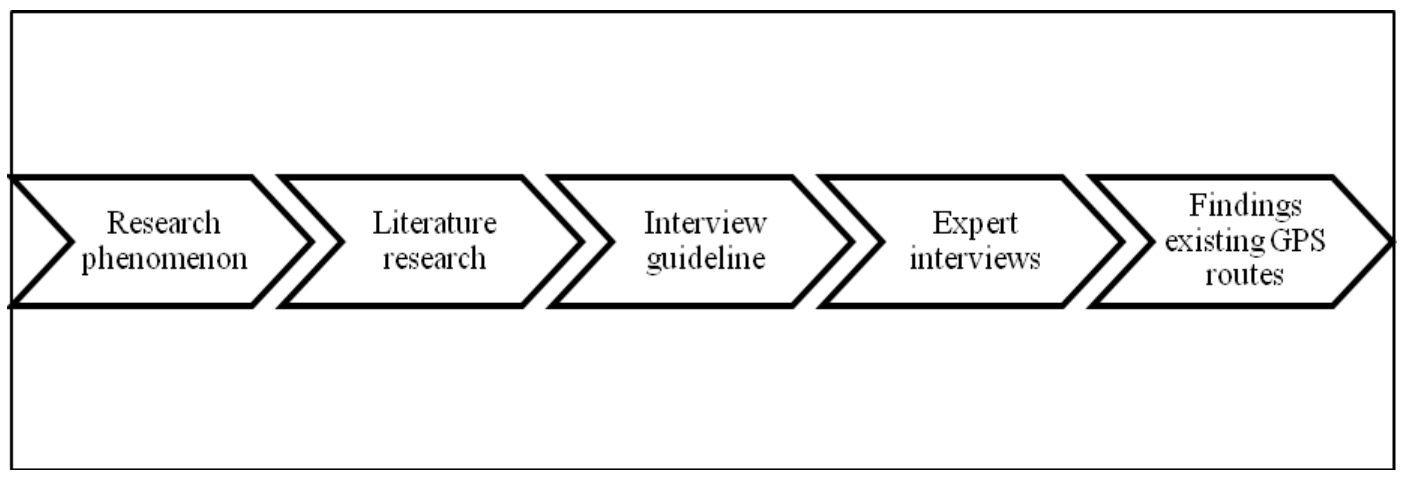




\subsection{Interviews and Sample}

The purpose of these interviews was to focus on the relationship between geocaching and environmental education. For this reason, the author chose a qualitative-explorative research design. As a consequence, some of the gaps in this field of investigation might be expected to be filled.

In order to gain new information and to fill some holes in the scarce literature, interviewing experts is the main part of this investigation. The definition of 'expert' depends on the area of investigation (Meuser 2005, p.443). Therefore, the sampling of expert interview partners purposefully followed a broad set of criteria. The experts should be individuals who are experts on either geocaching or environmental education. The first interviewee is a German expert in geocaching (interview partner IVP 1). He has his own business and develops GPS routes for corporate events. The second expert studied agricultural science and has been working in the area of environmental education for a long time on a self-employed basis (interview partner IVP 2). After meeting them, the author searched for people who developed geocaching routes for use in environmental education. Two people were chosen. Expert 3 has a Masters in Geoecology. He arranges his geocaching routes without hiding the caches, using outstanding points in the terrain, known as "earth caches" (interview partner IVP 3). Interviewee 4 has a Masters degree in environmental education (IVP 4). In her as-yet unpublished Masters thesis, she develops a geocaching route together with the help of some teenagers. At the moment, she is employed as a social worker. The author chose these experts in order to obtain a lot of information. There are no private relations between the author and these persons.

This is an explorative study for further investigation. For this reason, the number of interviews was limited, as the gaining of information was the most important factor; the number of interviews was chosen in such a way as to gain as much information as possible. During the interview period, the author started to analyse the interviews in order to see if the interviews had yielded new information or not. When the author noticed that there was no more information left to gain, the interview process was stopped (Johnson 2002, p. 113). The interviews took place between December 2011 and February 2012.

\subsection{Interview Guideline}

The four interviews (interview partners 1 , 2, 3, 4) followed a specially-designed interview guideline. The interviews were based on a semi-structured interview guideline with open-ended questions (Flick 1991). The interview guideline was based on suggestions from literature (theoretical section). All dimensions covered in the framework were backed by relevant questions. The guideline consisted of two parts, which will now be described.

-The first part deals with the relationship between geocaching routes and the different aspects of environmental education as presented above.

-The second section deals with the specific requirements of a cache for use in environmental education, with regard to the different aspects presented in the theoretical part. The questions asked about the type of caches are used according to which methods are integrated in the cache tasks or how people in charge integrate the participants' lifestyle.

The interview guideline allows the results of the different interviews to be compared more easily (Gläser 2006, p. 39 et seqq). Each interview was transcribed and kept in the participant's own words to reflect 
the interview as closely as possible.

\subsection{Existing geocaching routes with aspects of environmental education}

Another part of the material is the selected geocaching routes, which were created by different environmental education organizations in Germany, such as: Fischotterzentrum Hamburg, or Schutz (Umweltbildungszentrum der Hansestadt Lüneburg = Environmental Education Centre of the city Lüneburg). These routes were selected because they to some extent reflect specific aspects of the definition of environmental education (2.1.). Later in this article, the geocaching routes and their caches will be used to illustrate the information gleaned from the interviewees. In brief, the selected GPS geocaching routes are the following: The first example is the Wandse-Rallye with focuses on the topic 'The habitat of flowing waters' and is situated in Rahlstadt, a small village near Hamburg. This geocaching route follows the Wandse river, which is located in the residential area of Rahlstedt, Hamburg. In nine caches, the participants interactively collect information about the river Wandse from different perspectives (Ecomove 2011 A). The second example is the paddock route near Boberger in the north of Germany. The theme 'Amphibians and their habitat' is illustrated through eleven caches (Ecomove 2011B). Another example is the "GPS Route", which is situated in Hamburg. Its main aim is to inform teenagers about otters in an interdisciplinary way . The selected GPS routes are unique in their own way and show the many possibilities for creating a cache for use in environmental education (Aktion Fischotterschutz 2011). Another good example is the Green Belt Area geocaching route. This area is the former frontier region between West and East Germany, which was left to nature after reunification. The teenagers developed the caches on this route by themselves. The contents of the caches deal with the theme 'Green Belt Area' from different perspectives (Schubz 2011). The selected GPS routes for this project are likewise unique in their own way and each shows how caches can be created for use in environmental education.

\section{Results}

In this section, the most interesting results will be discussed. In each case, quotations from the interviews will be used for answering the questions and describing the geocaching routes.

\subsection{Geocaching routes and environmental education}

First, the author tried to find an answer to the question: What are the specific characteristics of a good geocaching route for use in Environmental Education as defined in the theoretical section?

There are two possible methods for incorporating geocaching routes. "As a first option, the juveniles follow a geocaching route that is already prepared for them. Another option is that they create a geocaching route on their own." (IVP 1) The author will first deal with pre-prepared geocaching routes.

The first step is that the responsible person develops an overall concept. Each cache should communicate one section from one perspective of the main topic of the route. "I try to connect each cache to the central theme of the geocaching route. As a consequence, the overall topic will be treated in a more detailed way and from various perspectives." (IVP3) A good example is the geocaching route in the Green Belt Area. One Point of Interest (POI) deals with the ecological aspect of this region; the vegetation of this area. The second POI deals with the development of frontier tourism towards 
nature tourism from an eco-aware perspective. The last POI explains possible means to protect the area (Schutz 2011). Thereby, the teenagers acquire knowledge and information in an interdisciplinary manner and then consider environment in its totality (natural, artificial, technological, ecological, moral, aesthetic). This goes along with the postulations of the environmental education (Siva Laxmi 2010 , p. 15). For this purpose, the area in which the geocaching route is going to be installed will have to be explored very precisely, so that different aspects of a theme can be integrated.

The geocaching route should also have a relation to the daily life of the participants. "There are different opportunities to integrate the life of the juveniles: one possibility is they create their own route [...] First, I go with the children to an existing geocache, so that they see what a geocache looks like. Then they decide on their own the theme of the geocaching route and the aspect they want to conceal in their cache. The consequence is that the participants have to cooperate from the beginning." (IV4) This factor is vital for a successful training activity. The participant must incorporate the activity in her daily life. This in turn impacts the motivation of the participant; she becomes more active, which is a very important aspect of environmental education (Siva Laxmi 2010 , p. 15). If the participants create their own geocaching route, they have to decide on the theme of the geocaching route and fix the locations of the caches. For a successful operation, they need to cooperate in a group and find a solution together. This form of cooperation is also part of environmental education (Siva Laxmi 2010, p. 15). The element of incorporating the activity into everyday life can come from the regional aspect, provided that the geocaching route is in the participants' own environment.

After talking about the geocaching route and environmental education, now we will move onto the possible relationships between caches and environmental education.

\subsection{Caches in relation to environmental education}

In order to employ geocaching for educative means, it is necessary to answer the question of what the specific characteristics of a cache in terms of environmental education should be. The place where the cache is installed plays a very important role. "Caches are specially located so they stand out from their surroundings because they are particularly unique and interesting or suggest cultural and historic facts" (IVP 1). First, participants have to investigate an area to find these interesting points and mark them in a map, so that they can later choose the locations they then want to use for the cache. "You have to remember that nature is always moving. Certain plants appear only at a certain time, animals move as they please. In some ways, therefore, geocaching can not react spontaneously" (IVP 2). This fact must be considered in the selection of the cache location. Not every place is suited to provide the participants a good insight into the nature of the selected area. Next, the form of the cache should be decided. The interview partners agreed that often, traditional caches are used for the routes, because they are easier to handle. Earth caches are a special form of cache. "Earth caches are one example. They do not have a physical cache container. Earth caches are special places that you can visit to learn about a particular aspect of Earth science. (IVP3) The cache locations always treat a certain aspect of nature, enabling people to be better informed about certain aspects of nature in an interactive learning process, which 
fits well with the prerequisites of environmental education (Siva Laxmi 2010 , p. 15). One problem must be mentioned here, which all interview partners mentioned. "People have to take care where they install the cache. Some nature areas are very sensitive, and if a lot of people go there to find the cache, they could destroy the natural surroundings $[$...] another problem is that the cache boxes can get lost (IVP 2)". Therefore, one good possibility is to use earth caches, because you do not have cache boxes, which can get lost in nature.

The contents of the caches are very interesting from an environmental education persepective. The tasks in the caches can be used to focus on the current or potential environmental situation. "One example is from a geocaching route called the Maisinger gorge. [This GPS route is in the south of Bavaria, in the eastern part of Starnberg]. In one cache, the participants have to look closely at the stones in the rivers. They have an unusual appearance, as they are from the Ice Age. For example, small white lines appear on the stone, which are evidence of the same high pressure which caused the Alps to form. Because of these forces, the stones broke and the fractures were refilled with minerals" (IVP3). It is important that the tasks in the caches appeal to different senses, such as observing vital details as described above, touching, smelling, and listening. This leads to a greater learning effect and the participant can develop sensitivity to environmental phenomena, which has an important role to play in developing environmental awareness (Siva Laxmi 2010 , p. 15). "In the field of environmental education there are different methods you can use as experiments or interviews" (IVP 2). Some more examples can be gleaned from the geocaching route named Wandse-Raylle. There, the second cache is about erosion of the area along the river banks. In the third cache, the juveniles have to analyse the flow velocity of the river and the depth of the water. In the fifth cache, the juveniles analyse the water temperature (Ecomove 2011). These different methods help to develop skills to analyse environmental situations. At the same time, participants learn to co-operate in groups to fulfil the tasks. This thereby fosters improved communication within a group of people who interact or work together (Siva Laxmi 2010, p. 15). A good opportunity to improve people participation is demonstrated by the geocaching route of the biosphere reserve along the river Elbe. It was not a single person who decided that this is the most interesting POI in the Route; the people themselves chose this through internet voting. They can still submit their opinions on the different caches via the internet (Schutz 2011). A deeper form of participation is that "the teenagers have worksheets, on which they note their findings and later on, they upload their findings onto the Internet on a special website where they can discuss them with other people."(IVP 2) This approach also improves their reflection on their own experiences of nature and can help to develop awareness of environmental themes, which is an important aspect of environmental education.

\section{Conclusions of the results}

The discussion about environmental education and geocaching routes has shown that this combination potentially offers a lot of possible opportunities, but there are also problems. First, the author will discuss the problems.

\subsection{Problems}

The technical problems that can occur when using a GPS device will not be mentioned here because they are not 
specifically related to the question of geocaches in environmental education. One disadvantage when using GPS for environmental education is that a lot of things in nature only appear for a certain time. Many plants are seasonal and animals move freely in nature. Natural features do not always appear in the same place at the same time. As a consequence, these aspects cannot be taken into account in a fixed geocaching route. At certain points, the method is very statistical. This finding goes along with the disadvantages mentioned by Schäfer (2010). Also, the participants have to be aware of the fact that they do not wander off the established trails, as this can damage vegetation and harm other natural or cultural resources. These arguments confirm the findings of Patubo (2010).

\subsection{Advantages}

Besides the problems, there are also advantages. "People that normally have no intention to participate in environmental education programs can be attracted to it. In comparison to the normal environmental education programs, you do not have to listen to a guide. You just go out and learn something about nature with the help of geocaches." (IVP3) A very important aspect is therefore that you can reach a group of people with this method, who are not normally attracted by standard environmental education programs. "Often this method is used for teenagers, who are not attracted by the normal environmental education programs." (IVP3). These people spend time in nature. With the help of geocaching, they are doing what they otherwise would not do. Without having had these nature experiences, these youngsters would not know what they should be protecting (Brämer 2006, Lude 2005, Zecha 2010). As it can be seen in the presentation above, there are possibilities to integrate the different aspects of environmental education as defined in the theoretical part. Knowledge about the environment can be taught in a geocaching route. It is very important to highlight that the tasks in the caches treat their theme in an interdisciplinary way. The methods which are used in the caches are very important. They have to be varied, improved skills and help identify environmental problems. Environmental attitudes and awareness are difficult to influence as psychographic variables, particularly by short-time interventions. Attitudes towards and awareness of the environment can only be influenced when people develop feelings for nature. However, this aim lofty can be said to have been reached by some of the creative settings in which the caches have been deployed.

The best and most effective method with regards to environmental education is when pupils create their own geocaching route. This allows for the routes to be incorporated into their daily life. They look for the special locations to install the cache. They develop the task of the cache themselves. An extension of this is that you upload the created geocaching route onto the internet so that other people can use the route themselves. In an Internet forum, they discuss the results of some caches and look for further information. This is a very important step in integrating student participation.

The discussion of the results shows a very interesting response to the question of whether geocaching routes can be used for environmental education. Most of the negative aspects, for example the impacts on nature confirm Schäfer (2010) and Patubo's (2010) earlier studies. The author of this study has discovered some positive ways in which geocaching can be used within environmental education. 


\section{Outlook}

The focus of this explorative study was to show how geocaching routes can be used within environmental education. The findings can be used for further studies. No geocaching route which really treats all aspects of environmental education equally has existed up to now. It would be very interesting to create one and see how this geocaching route influences the environmental consciousness of people, which is the aim of environmental education. For this aim, the geocaching route should be accompanied by a preand post- test design, which consists of a questionnaire. Environmental education is an active subject that comes to life when the learner acts in it rather than hears and reads about it. One possibility surely is geocaching routes.

\section{References}

Aktion F. (2011). Die Otter Rallye, Hamburg (unpublished). [Back to text]

Brämer, R. (2006). Natur obskur. Wie Jugendliche heute Natur erfahren. München: Oekom Verlag GmbH. [Abstract] [Back to text]

Burt, L. (2010). GPS and Geocaching in Education.

http://www.iste.org/images/excerpts/

GCACHE-excerpt.pdf (20.04.2011).

[Full text] [Back to text]

Christie, A. (2007). Using GPS and Geocaching Engages, Empowers and Enlightens Middle School Teachers and Students. http://alicechristie.org/pubs/E6/index. $\underline{\text { html (19.03.2011) [Full text] }}$

[Back to text]

Cornell, J. (1991). Mit Cornell die Natur erleben. Oldenburg: Verlag an der Ruhr. [Abstract] [Back to text]

Dobyns, D., a.o. (2008). Educaching: capturing the spirit of the hunt for learning. NAGC Annual Convention, Minneapolis.

[Back to text]

Ecomove International (2011). Roadbook Kreuzkröten-Tour.

http://www.abenteuer-

wasser.de/fileadmin/ecomove/Roadbo ok Boberg.pdf (22.04.2011) [Full text] [Back to text]

Ecomove International (2011). Roadbook Wandse-Rallye.

http://www.abenteuerwasser.de/fileadmin/ecomove/Roadbo ok_Rahlstedt.pdf (22.04.2011). [Full text] [Back to text]

Flick, U. a.o. (1991). Handbuch Qualitative Sozialforschung. Grundlagen, Konzepte, Methoden und Anwendungen. München: Beltz, Psychologie-Verlag-Union. [Abstractl] [Back to text]

Gläser, J., a.o. (2006). Experteninterviews und qualitative Inhaltsanalyse als Instrumente rekonstruierende Untersuchungen. Wiesbaden: VS Verlag. [Abstract] [Back to text]

Groundspeak Team (eds.). (2010). The language of location. Seattle. www.groundspeak.com

(21.11.2011) [Back to text]

Gründel, M. (2009). Outdoor Handbuch aus, Basiswissen für Draußen, Band 203: Geocaching. Welver: Conrad Stein Verlag. [Abstract] [Back to text] 
Hartl, D. a.o. (2006). GPS und Geocaching als Medium der Umweltbildung. In: T. Jekel, a.o., Lernen mit Geoinformationen, (pp. 70-78). Heidelberg: Wichmann. [Abstract] [Back to text]

Ihamäki, P. (2007). Geocaching at the Institute of Paasikivi - New Ways of Teaching GPS Technology \& Basics of Orientation in Local Geography. ICTA 07 Tunisia, 155158. [Full text] [Back to text]

Johnson, J. (2002). In-depth interviewing. In J. Gubrium \& J. Holstein (Eds.), Handbook of interview research. Context and method (pp.103-119). Thousands Oaks: Sage Publications. [Abstract] Back to text]

Koller, A. (2010). Geocaching - Ein Impuls für den GW- Unterricht?! GW- Unterricht, 119, 58-64. [Full textl] [Back to text]

Lude, A. (2005). Naturerfahrung und Umwelthandeln - Neue Ergebnisse aus Untersuchungen mit Jugendlichen. In U. Unterbruner (Ed.), Natur erleben. Neues aus Forschung \& Praxis zur Naturerfahrung (pp. 65-84). Innsbruck: Studien-Verlag. [Full text] [Back to text]

Meuser, M. a.o. (2005). Experteninterviews- vielfach erprobt, wenig bedacht. Ein Beitrag zur qualitativen Methodendiskussion. In A. Bogner, a.o. (Eds.), Das Experteninterview, Theorie, Methode, Anwendung, (pp. 71-95). Wiesbaden: VS. [Abstract] [Back to text]

Navi Natur (2010 April). GPSBildungsrouting. Methode zur
Partizipation von Schülerinnen in einer Bildung für nachhaltigen Entwicklung. Dokumentation der Fachtagung Wedel (BNE), Lüneburg. [Full text] [Abstract] [Back to text]

Patubo, B. (2010). Environmental impacts of human activity associated with geocaching. California Polytechnic State University research paper. 18 p. [Full text] [Back to text]

Riess, W. et al (eds.) (2006). Bildung für eine nachhaltige Entwicklung. Aktuelle Forschungsfelder und ansätze. Wiesbaden: VS. [Full text] [Back to text]

Schäfer, L. (2010). NaTOUR Umweltbildung mit GPS. Entwicklung von Inhalten des Edutainment für eine Beispielstrecke zum Naturerleben im Raum Oldenburg. Oldenburg (Bachelorthesis). [Full text] [Back to text]

Schleicher, K. (1997). Umweltbildung im Lebenslauf. In K. Schleicher, Umweltbildung im Lebenslauf. Altersspezifisches und generationenübergreifendes Lernen. Umwelt - Bildung Forschung, Bd. 1, Münster: Waxmann Verlag. [Full text] [Back to text]

Schleicher, Y. (2006). Digitale Medien und E-Learning motivierend einsetzen. In H. Haubrich (Ed.), Geographie unterrichten lernen, (pp. 207-221). Stuttgart: Oldenbourg Schulbuchverlag. [Full text] [Back to text]

Schubz (2011). Grünes Band, Lüneburg. http://www.navinatur.de/t3/index.php 
Geographical issues and

$\underline{\text { ?id=9. }} .(9.6 .2011) \quad$ Back to text $]$

Siva Laxmi, G.V. (2010). Methods of teaching. Environmental science, New Delhi: Discovery Publishing House. [Full text] [Back to text]

Telaar, D. (2007). Geocaching. Eine kontextuelle Untersuchung der deutschsprachigen GeocachingCommunity. Münster. (Masterthesis) [Back to text] [Full text]_Abstract]

Tully, C. (2004). Neue Lernkonzepte in der Informationsgesellschaft? - In C. Tully (Ed.), Verändertes Lernen in modernen technisierten Welten. Organisierter und informeller Kompetenzerwerb Jugendlicher (pp. 11-25). Wiesbaden: VS. [Abstract] [Back to text]

Tyszkowski, S. (2009). Geocaching as a geography education method for natural hazards teaching. In D. Schmeinck (ed.), Teaching Geography in and for Europe. innovative approaches (pp. 171179). Berlin: Mensch und Buch Verlag. [Full text] [Back to text]

Unesco (1978). Tbilisi Declaration. http://www.cnr.uidaho.edu/css487/Th e_Tbilisi_Declaration.pdf (22.12.2011) [Full text] [Back to text]

Umweltbildungszentrum der Hansestadt Lüneburg (SCHUBZ) (2010). NaviNatur Das Projekt.- Web: http://www.navinatur.de/t3/index.php $\underline{? \mathrm{id}=20}(22.01 .2011)$ [Abstract] [Back to text]

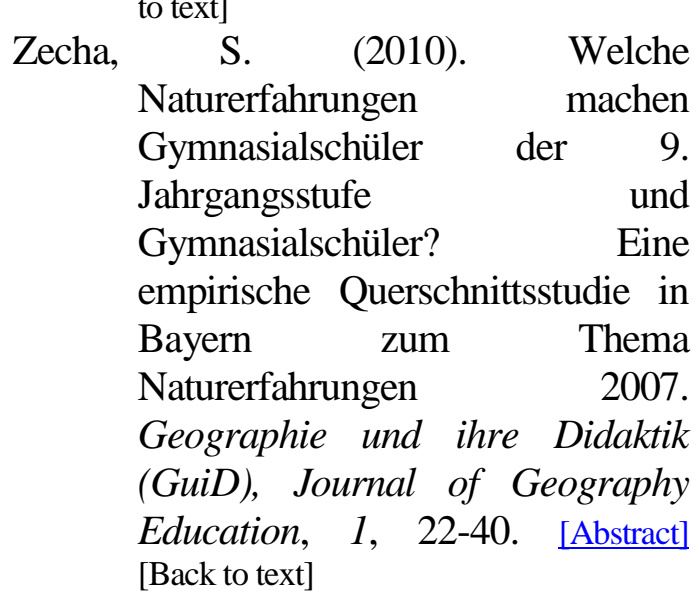

